\title{
In the Labyrinth of Forgetfulness: Charley Grainger's Joycean Journey in Christine Dwyer Hickey's Cold Eye of Heaven
}

Contemporary Irish writers, such as Mike McCormack, Anne Enright and Donal Ryan, usually place their works in relation to their auspicious forerunner James Joyce, envisioning their own contributions as having been inspired by his works. ${ }^{1}$ Acknowledging this correlation, Christine Dwyer Hickey sees herself as both a Dublin writer and a writer of Dublin. ${ }^{2}$ Joyce is for her what Yeats was for Joyce and what Virgil was for Dante, ${ }^{3}$ a guide through the world of literature. Published in 2011, Cold Eye of Heaven narrates the life of Charley Grainger, known as Farley, ${ }^{4}$ through events unfolding backwards by decades, from January 2010 to December 1940. Hence, the results of his earlier decisions

1 Corcoran (112-130) explores the interactions between contemporary Irish poets and novelists and Yeats and Joyce.

2 The Irish Times, Fri., Jul 24, 2015, 09:31 (accessed March 22, 2021) https://tinyurl.com/ yrcveue3. Hickey's trilogy, The Dancer (1995), The Gambler (1996), The Gatemaker (2000), narrates the story of a Dublin family set against the tumultuous times of wwi till after wWII. It is not coincidental that she entitled her short stories: The House on Parkgate Street and Other Dublin Stories (2013).

3 Welch, citing Richard Ellman, sees Yeats as Joyce's Virgil, "mentor and warning" (105, italics original).

4 There is an American under the name Farley in Joyce's "After the Race" (2000c), but this Farley is not in any way linked with Hickey's characters. 
are presented at the opening of the novel, and the reasons for these decisions at its end. The episodes unhurriedly expose what has been forgotten or silenced in Farley's life, exposing the circularity of human existence, enclosed in the space of decades, concluding with: "A man, a boy, a child, a baby, a man again, all at once" (Hickey 2012: 215). The use of the reversed chronology shows the protean nature of the storytelling and life itself, demonstrating the hero's literary, but not literal rebirth. Farley's is the metaphorical journey of every human being or, rather, the allegorical journey of Everyman. Unlike Everyman, however, Farley does not know that he has reached the ultimate stage of his life, but like Everyman, he is not ready to present his "book of reckoning." The first two chapters of the novel show the character's final moments, when, having collapsed in the bathroom, he lies dying, lost in the labyrinth of his mind, thinking about the long-gone past; a day before this happens, he roams through the known-unknown places in Dublin, the Dublin of the post-Celtic Tiger, but pre-Brexit times, echoing the xenophobic discontent of the earlier era. Bloom's and Dedalus' rambling in Ulysses takes place on a June day at the beginning of the twentieth century, offering a wide range of situations and characters, whereas in Hickey's account, the post-war history of Dublin, is compressed within the span of Farley's earthly sojourn. ${ }^{5}$ In this way, various events in Farley's life overlap with the rise and decline of the capital. ${ }^{6}$ As a result, in their distinctive approaches, yet true to the nineteenth century formula, both novels are the mirrors of their respective realities. What follows, then, is the analysis of Farley's labyrinthine wanderings, both metaphorical and real ones, offered at the beginning of the novel, with reference to the changes in the city and attitudes to its inhabitants, as well as to strangers, dispersed throughout the narrative.

In Cold Eye of Heaven as in Joyce's Dubliners, the action of the chapters spans from a few hours, to a day, thereby capturing significant moments in the main character's existence, albeit always in conjunction with the historical

5 Bloom begins his day by talking to the cat, who replies in cat language: "Mrkgnao!" (Joyce 1990: 55), and Farley ends his day by lifting the cat, Shifty, to his arms and feeling "warmth, strength, frailty, life" (Hickey 2012: 47).

6 If one looks at the growth of the city subsumed within a circular motion and repetition, in a way Farley's observations of Dublin can be examined through the pattern of Yeats' gyres, outlined by the poet in the apocalyptic "Second Coming"; where the gyres "widening" signifies that they are further and further away from the center, its point of origin, while human history takes a violent turn. In "The Gyres" Yeats predicts the deaths of cultures, which die having exhausted their own "intellectual, imaginative, and ethical power," but the poet hopes that the motion of the gyres will help "resurrect an older form of life" (Vendler 94). The Yeatsian understanding of history, however, falls beyond the scope of the present paper. 
development of the city. Farley's penitential expedition, in preparation for the funeral of a former colleague, evokes the medieval representation of the mind as a labyrinth, the meanders of consciousness as mysterious as the structure of the brain itself. Such images allowed medieval thinkers to create a palpable model of personality. Modernists, in turn, attempted to recreate the way in which the human mind associates and recreates ideas, using the famous stream-of-consciousness technique, aptly rendering an individual perception of reality. Farley's tale is evidently told in a non-linear mode as he fuses the past and the present in his mind, moving in and out of the timeline of events. The narration is, on the one hand, suggestive of the working of his fuddled memory; on the other, of the labyrinthine forking paths. ${ }^{7}$ In a manner evocative of Beckett's Malone from Malone Dies, ${ }^{8}$ he tries to calm down by telling himself stories of his father who: "Died of a stroke, or six months after a stroke, though the stroke was the cause of it" (Hickey 2012: 4). Though he does not remember the exact cause of his anxiety, he recalls a scene when "his young self for a moment, clutching the bars of the garden gate, with his brown hair and sticky-out ears, [was] like a little monkey in short pants, bawling his brains out" (Hickey 2012: 5). Details from his early life return to him with force, yet he cannot envision his nextdoor neighbor, the father of three children and the husband of a woman he calls "Mrs Brown-eyes" (Hickey 2012: 4). Aggrandized by the loss of recollections, the stupefaction is symptomatic of dementia. To underscore the character's sense of perplexity, Hickey portrays him as lost in time. Farley "keeps losing moments ... like they're falling out of a hole in his pocket" (Hickey 2012: 44). Indicating a progressive neurological disease, the character wakes up with a "recurring blur," and seems to feel nothing, remembering solely: "the dark space of dreamless sleep" (Hickey 2012: 1). The hazy vision has nothing to do with the effect used in impressionist paintings, but is somewhat analogous to Stephen Dedalus' Berkeleyan experiment of closing his eyes to find the world changed upon opening them again (Joyce 1990: 37). In the end, Farley's former self vanishes in the tangle of forgetfulness, and he is no longer able to navigate through the labyrinthine structure of his memories.

As noted above, the metaphors of mazes and labyrinths have existed in the European imagination since Antiquity. In the first instance, they refer to the verb "amaze," but in Old English the word also meant to "confuse" and "confound," as

7 Farley is aware of his loss of memory. At some point, looking at the missing roundabout, he thinks about the Berlin Wall, which prompts him to ponder "about the state of his mind, all the things muddling around inside it" (Hickey 2012: 29).

8 Beckett (1958: 179-288), In his monumental biography of Beckett, Anthony Cronin calls him "the last modernist" (1996). 
well as "astonish"; in one Norwegian dialect, David Wills McCullough asserts, the word meant not "disorientation" but "loss of consciousness." In the novel, Farley battles intermittent headaches and waves of nausea. Listening to his own heartbeat (Hickey 2012: 5), he oscillates between the present and the past, trying to survive until, as he thinks, his Polish neighbor will be leaving for work and he can call for help. He needs to muster all his strength because his right side is paralyzed, and he seems unable to utter a word (Hickey 2012: 2). Moreover, he is not certain what day of the week it is, though he deduces that it must be Monday, because the dry-cleaner is not open on Sundays (Hickey 2012: 8). These early morning reveries are filled with introspection, but marked by progressive physical and mental weakness; his inability to properly close his mouth being one of the signs of a stroke. "For some reason the dry-cleaned suit comes into his head. He searches for the colour, the texture of cloth. The pinstripe navy? The charcoal grey? Or was it the black-funeral black?” (Hickey 2012: 11). Here the maze of memory falls under the definition of "the labyrinth as a difficult process" (Doob 65)..$^{10}$ The complex, ostensibly inextricable mythological pattern can thus be used to contextualize Farley's sense of unreality. "He has a feeling he has to be somewhere tomorrow, or-depending on what time it is now-that it could be today. Somewhere important" (Hickey 2012: 2). His uncertainty, fear, irritation as a result of sensory limitations, and the impossibility to remedy the current situation, imply that his is indeed the last journey. Not only is he unable to get up from the floor, he is also incapable of logical reasoning: "Farley regrets. What? He isn't quite certain" (Hickey 2012: 3). In this most terrifyingly lonely moment, he associates the lamp-post outside his bathroom window with "the cold eye of heaven" (Hickey 2012: 3); but heaven has just turned from him-or, perhaps, it is now watching him, calling him to present himself at its gates.

Superimposing a Beckettian "endgame," Hickey's focus is on the older, lonely Farley, while Joyce portrayed Bloom in his middle years accompanied by the young Stephen Dedalus. Bloom might not be Everyman, but, as Declan Kiberd states, he is "the embodiment of community values" (343). Elderly Farley, who hates being called a senior because that title "makes him feel like he's been back in primary school" (Hickey 2012: 32), can nevertheless be seen as the epitome of the ageing European society. "Ireland is the old sow that eats her farrow," declares Joyce in A Portrait (200ob: 171), undermining the image of Ireland romanticized

9 In Chaucer's Troilus and Criseyde, for example, it referred to a "trick," when the author wrote "all this was but a maze" (McCullough 15).

10 The other two definitions being "the labyrinth as a sign of complex artistry" and "of inextricability" (Doob 65). 
through the figure of Cathleen ni Hoolihan, reborn as a young and beautiful woman in Yeats' 1902 play. The new, Celtic Tiger Ireland attracted not only its own youth, but immigrants from Britain, identified as non-Irish, ${ }^{11}$ and those from the extended European Union, with Polish immigrants being the largest group (Fanning 2011: 51). ${ }^{12}$ Studies, such as Bryan Fanning's, corroborated that the lack of neighborhood acceptance was the dominant feature among Polish and Lithuanian migrants (2011: 52). It comes as no surprise, then, that Farley's neighbors, a Polish woman and her three flatmates, are described by him as: "Tall, high-arsed, fairish. A touch of Luftwaffe about them" (Hickey 2012: 7). He imagines them asking "'What?' they'll say. 'What?' (or whatever the Polish equivalent would be) ... 'Tak', they might say ... Tak is for yes, zaden-was it? Zaden means no. Or maybe it was the other way round" (Hickey 2012: 7). Correlated with the waning of the Celtic Tiger is the rise of the number of the former East European countries citizens living in Ireland, this, in turn, contributing to the growing challenges for the maintenance of social cohesion and inclusion. Yet, discrimination and various barriers to assimilation have to be seen with reference to a particular group.

The post-2003 immigration from Poland, for example, was mostly economic; integration "was understood as integration into the economy" (Fanning 2009: 21). Farley's observations concerning his Polish neighbors, however, have more to do with loneliness than his particular dislike of them; after all, he does not engage with his Irish neighbors either. They are "[p] eople he might never have even spoken to, beyond an occasional nod or a 'not a bad day after' in passing" (Hickey 2012: 17-18). Nonetheless, the rather offensive description of the Poles reverberates with the concurrent recognition and depreciation of immigrants, the nation-state ideology being the direct result of the prolonged struggle for independence aggravated by the still-unsolved problems in the North. According to Bryan Fanning, "In 2004 the Irish nation as a political entity retreated into

11 Interestingly, during his walk home after the retirement party, Farley was stopped at the Four Courts bridge by a man, whom he immediately recognized as "not-Irish" (Hickey 92). As it turned out, his sing-song accent was Welsh. This scene points to the new approach to immigration, as it is not the Irish who leave the country in search of better living conditions but the British who recognize the economic potential of the Celtic Tiger. In 2001, the Irish Nationality and Citizenship Act was issued, superseding "the Aliens Act" (1935), replacing the term "alien" with the term "non-national" (Fanning 2011: 45). The younger Farley's perception of the city on an April evening as he looks at the river, imagining people in well-lit houses noticing him, stands in marked contrast to the wintry city of 2010 suffering from recession.

12 I am grateful to Dr. Katarzyna Gmerek, who drew my attention to Fanning's work. 
a nineteenth-century definition of nationality as a defensive response to immigration" (2009: 2) $\cdot{ }^{13}$ Hence, the political and the literary debates concerning nationhood become nostalgic musings of those who yearned for the ideal that never materialized, of "the same people living in the same place" (Joyce 1990: 331). In Ulysses, the rather ironic, albeit true, pronouncement generates laughter and sneers amongst those present in the pub, and the questioning of Bloom's Irish identity, despite the fact that he was born in Ireland. ${ }^{14}$ Bloom, voicing Joyce's anti-nationalism, sees it as: "Perpetuating national hatred among nations" (Joyce 1990: 331 ). ${ }^{15}$

Irish nationalism has always been connected with the process of glamorizing Irish history, in Kearney's terms wresting "fictional triumph from historical failure" (2002: 20). Fanning terms it as the colonization of the Irish past, which is consecutively projected onto the future (2009: 11), based on the assumption of a rather stagnant "Irishness." Already in A Portrait Joyce remarked that " $\mathrm{t}]$ he Ireland of Tone and Parnell seemed to have receded in space" (200ob: 155). Still, Parnell remained for him an important figure, crushed by his own countrymen. "They did not throw him to the English wolves: they tore him apart themselves" (Joyce 2000a: 196). Recognizing the importance of the Irish Revival, at the same time opposing its "folkish, even folksy" elements (Deane 38), Joyce's involvement in the cultural movement was not that of a politician, but of an artist protecting his own artistic freedom. He was aware that the country was in a state of flux, its national identity persistently subject to the opposing forces of urbanity and provincialism. This was the axis on which Joyce based his vision of Irish history. Even if for Stephen Dedalus, history was "a nightmare" from which he was "trying to awake" (Joyce 1990: 34), Joyce was preoccupied with continuity, with preserving what was left in the Irish culture, conquered not only by the English but also by the English language. In his locus classicus on imagined communities (2006), Benedict Anderson views nineteenth-century nationalisms, themselves the product of a changing world, aiming to re-define

13 Welch, discussing the issues of stasis and change in Irish literature, claims that literature needs transformation as the creative spirit does not tolerate inertia (ix-xi). For him, "change and stasis continually recreate one another" (7).

14 The nuanced, ever-present, antisemitism is also a subject matter of The Narrow Land (2019), where a young wwII Jewish refugee, who is being given a new name and a new language, is spending the summer with an American family, and in the earlier Last Train to Liguria (2009), which traces the rise of Fascism and antisemitism in pre-war Italy.

15 Garrett Deasy, who embodies loyalist and anti-Semite attitudes, is one of the most despicable characters in Ulysses, whose hatred of Jews and women make him avow the conspiracy theory of history. For more, see Paziński (31-32, 203-204). 
national identities. For him, the actual existence of "imagined communities" assumed that nationalism was synonymous with patriotism, which, consequently, suggested an adherence to a conservative supremacist philosophy. Joyce as well as Hickey are more cautious in their support of Irish patriotism and the devaluation of insular nationalism. Although twentieth-century Ireland embraced the European Union's ideology of cosmopolitanism, modernization, and progress, the essentialist ideas, fashioned in the early phase of Irish nation-building - the "Irish-Ireland," as Fanning terms it-"remained a force to be reckoned with" (2009: 9).

The issue of "narrow gauge" nationalism, to use Kiberd's expression (350), has been discussed by contemporary researchers since the 1990s, especially in the context of religious and nationalist divisions. What R. F. Foster (1989) sees as the new nationalism of the early twentieth century, being both the cause and the result of the end of the nineteenth-century cultural movements of the Celtic Twilight, Kiberd reads as the processes geared towards re-inventing Ireland. Kiberd notices that Joyce was perceived to be rebuking militant nationalism, which for him risked "embracing the imperial psychology in a reworked form" (445). Joyce's mythical realism, after all, overlaid the classical voyage "against the Irish quotidian" (Kiberd 338), but like all epic writers before him, he was involved in nationalist issues by virtue of the genre. In the above-mentioned "Cyclops" episode, set in a pub in Little Britain Street, the citizen criticizes British violence only to become very aggressive towards Bloom, challenging his "Irishness" (Joyce 1990: 329-342) ${ }^{16}$ Written in the parody of epic style, and set in the area of one of Dublin's oldest churches, St. Michan's, housing the bodies of Henry and John Sheares, the brothers, who were killed by the British for organizing the 1798 uprising, ${ }^{17}$ the significance of the place for Joyce tackling Irish nationalism, was unprecedented. However, by virtue of having a drunken anonymous citizen pontificating on the Irish cause, Joyce undermined the genuineness of such conservative views, exposing the mechanisms of shaping the fallacious chauvinism of his compatriots. The chastisement of good-hearted Bloom is presented as a personal misadventure, aimed to be a warning against entering conversations with strangers in shady places. The Joycean Little Britain Street situated in the plebeian Smithfield is strikingly similar to Hickey's Westmoreland Street where Farley notices a group of foreign gypsies "whimpering a begging

16 Bloom, however, also embodies the commercial city: "it is not surprising that his vision centers on its commercial function. ... Joyce revealed the grotesqueries of commercialism" (Lehan 109).

17 For more see Pakenham (2004). 
prayer" and asking for change (Hickey 2012: 38). Farley does not engage with them, but his aversion and anxiety point to the class distance between different ethnic groups. The famous Four Courts building, located in the vicinity of Barney Kiernan's pub and standing in marked contrast to the poverty of the surrounding area, is mentioned by Farley in relation to his daily trips to and from work. This allusion provides yet another link between Joyce's and Hickey's characters' peregrinations in a multicursural labyrinth in the case of Bloom, and unicursural one in the case of Farley. Nonetheless, Bloom's as much as Farley's encounters draw attention to the issue of a nationalistic utopia saturated with the policies of belonging and non-belonging.

Outside the pub where Farley went for warmth, he reveals to the young woman, who, like Joyce's citizen is unnamed, that he neither smokes nor drinks, and the woman wonders how that is possible "in this country." Farley replies, "I'll tell you what it's like. It's like being a foreigner. It's like you don't belong here. Like everyone secretly hopes you shag off back to wherever it is you came from" (Hickey 40). ${ }^{18}$ Although this quote quite clearly references Muslims, whose religion prohibits them from drinking, indirectly, it concerns the elderly, sidelined by virtue of their lack of involvement in the economy and the social life of a community. In a few sentences, Hickey ties two important domestic issues: the vice of drinking and that of xenophobia. Besides Muslims, Fanning enumerates other groups marginalized in twentieth-century Ireland: Jews, Protestants, and Travellers. ${ }^{19}$ The last group features in Hickey's narrative as, in December 1980, Farley found himself "somewhere at the back of Oliver Bond flats. Black narrow streets giving way to a sudden sunlit clearing. A derelict site. A halting site for travellers ... a few caravans bunched to one side" (Hickey 2012: 124). This

18 In 1990, Farley wondered whether his new but not yet met sister-in-law, Jasmeena, was Indian. The question addressed to Jackie, his brother, shortly upon his arrival from London, was met with a shrug from Jackie. Farley's rather unfriendly inquisitiveness, even if it appears to be evocative of latent racism, is in fact, nothing more than curiosity concerning a stranger in the family (Hickey 2012: 90). In Hickey's short story “The Yellow Handbag" from the collection The House on Parkgate Street and Other Dublin Stories (2013), the main character is Indian, living in Dublin for the last fifteen years. Ashok works as a driver. Separated from his wife and daughter, he is a drifter, currently residing in his car. His story is compared with the one of the elderly Mrs Riddel who hired him to drive her through the sites of old Dublin, but is also, in a way, homeless, living in hotels following her husband's passing. Though coming from different ethnic and cultural backgrounds, their lives intersect, pinpointing the essential loneliness and rootlessness of the modern man.

19 Capitalization original in Fanning's work. 
description indicates the socio-spatial segregation, which according to Fanning reflects "class inequalities rather than prior histories of ethnic segregation" (2011: 66-67). It is clear that the prejudice towards Travellers is related to their refusal to conform with the country's goals of modernization; their itinerant existence being the very opposite to stable living and work conditions and the resulting contribution to the country's economy. Although Farley did not feel threatened by the group, even so, he was looked at like "some sort of a pervert" (Hickey 2012: 125). ${ }^{20}$ As was the case with his unease concerning the street junkies he met in 2010, the Travellers he encountered in 1980 also represented the category of Irish aliens, who, like Bloom, have been ostracized in the country of their origins.

As it transpires, "[p]resent day realizations of 'Irishness' have their historical antecedents. The prevalent categorization of immigrants as non-nationals suggests a cognitive continuity with past nationalist ethnocentrisms" (Fanning 2009: 109). ${ }^{21}$ Here is the paradox of Irish nationalism, which, in David Lloyd's oppinion, leaves most Irish writers "remarkably recalcitrant to the nationalist project" (89), yet equally compliant with idealizing intrinsic Irish culture. Bloom's Joycean alienation likewise calls forth his anti-ethnocentric sentiments, concurrently questioning and mythologizing the motherland. The criticism of nationalism in Joyce's citizen's comments marks the onset of the process of "postnationalization." Conversely, Hickey's novel advocates Kearney's dream of a "postnationalist" Ireland, ${ }^{22}$ strengthening the ideal of ethnic diversity, of an open, inclusive society. Still, when times are hard, older generations tend to fall back on their nationalist dream, dreading the presence of those whose cultures they do not understand. To this effect, analyzing the issues of order in the urban public space, identified as "a world of strangers," Lyn H. Lofland investigates the sociological impact of the arrival of newcomers into a community, perceived by

20 Fanning states that the high levels of illiteracy "kept Travellers not only from entering vocational education but also from internalizing the rules of belonging of a modernizing society" (2011: 23). Donal Ryan's All We Shall Know (2016) portrays two fictional families of Travellers portraying their hermetic society in a clash with contemporary visions of progressive Ireland.

21 Kearney reworks ideas on nationalism, dividing it into "civic," "ethnic," "romantic," "economic," "separatist," "sectarian," and "cultural" and described republicanism as "classical, modern and postmodern" (1997: 1). The nation state for him is always imaginary (1997: 2). He sees that "[ $t]$ here is a fundamental paradox coiled at the heart of modern republicanism" (1997: 27), which on the one hand promoted enlightened universalism but on the other permitted separatist nationalism (1997: 27; italics original, LS).

22 For more, also in connection with Joyce's remarks concerning Roger Casement in Ulysses, see Longley and Kiberd (45-74). 
more established inhabitants to be encroaching upon their space and ensuing in the fear of strangers (3-12). That unease is part of Farley's sauntering in the city: he cannot discern whether or not the taxi men were "eyeing him hungrily" as he stood outside the pub (Hickey 2012: 44). Surrounded by "Asian, Chinese, African" faces, Farley briefly contemplates the existence of racism in language and culture (Hickey 2012: 36-37). Thinking the bus driver is "as black as Foley" makes him meditate whether the expression had anything to do with the said Foley being perhaps a coalman (Hickey 2012: 37). Recalling a barman in the Four Courts Inn who used to have a dog called Nig-nog, and another acquaintance of his, Spencer, who claimed that "them blackies" were "stealing our jobs," even though Spencer had not had a job for at least twenty years (Hickey 2012: 36), Farley's deliberations bring to light cultural transformations in Ireland of the first decade of the twenty-first century; new linguistic attitudes towards people from other ethnic backgrounds being the foil to the changes in the Irish community itself. In the past, Farley's mother, for instance, used to have a coat, she called "nigger brown." In 2010 it was no longer polite to use such terminology, or to refer to black people as "colored" (Hickey 2012: 36). Sitting on the bus, Farley is less troubled by the new multiethnic Irish population, than by the homegrown "scumbags," who, impugning everyone for their "misfortune," would readily "rob the hair out of your head for a hit," as someone asserts (Hickey 2012: 35). No wonder, the feeble old man he is, he is constantly worried about being robbed: "He takes off his gloves and puts them in the Clery's bag, then slips his hand into his inside pocket. He can feel the pension book there, the wallet stuck in behind it. At least he wasn't dipped" (Hickey 2012: 35). Such statements feed the precarity of the pre-Brexit circumstances of the elderly while at the same time betraying the tenuousness of the sense of economic safety in the immigrant communities.

Hickey's twenty-first century city, the victim of the commercial crisis, seems to be on a downward trajectory, whereas Joyce's Dublin was an early twentieth-century city, stagnant in its parochialism, but booming with hopes to become a European metropolis. Both of these depictions show an affinity with the pattern of the rise and fall of ancient cities (Alter 140), especially Troy. ${ }^{23}$ Built into the stories of Bloom and Farley is a sense of a cyclicality of human history: "[C]ities rise and fall like the cultures that inform them"

23 Heinrich Schliemann's findings in Troy (1871) uncovered a number of cities built upon one another. This structure is equivalent to Ulysses (Lehan 111). Already in 1907, Joyce was toying with the idea of the parallels between the Irish and the Phoenician culture (2000a: 108-126). 
(Lehan 115; Joyce 1990: 61). Similarly, Bloom ruminates on the "[c]itiful passing away," (Joyce 1990: 164). Finding himself at the "the heart of the Hibernian metropolis," to use Joyce's expression (1990: 116), Farley discovers that places he remembered no longer exist:

"Nah.” The man shakes his head. "No shoemaker's, no bootmender's, no any kind of shops in the Liberties any more except those all-night jobs selling overpriced rubbish, rubbish. That's Baker's pub gone-remember Baker's Yea gone. And Roger's, that was a grand pub, for a quiet pint like when you'd wouldn't want to run into anyone. And of course Frawley's. Did we ever think we'd see that day?" (Hickey 2012: 37)

“The Indian chap," whose newsagent shop substituted the shoemaker's, is polite but not helpful. He does not remember what was in this place before he took over (Hickey 2012: 28). Change, of course, is written into the unstoppable historical processes, yet for Farley, the "new" Dublin embodies his own frail condition, and through the gaps in his memory the author of the novel validates her vision of not so much the autumn as the winter of human life. Farley finds himself in a place he knows, but does not recognize: "Everything is different and yet he knows it's still the same. The roundabout is missing; that's it. The roundabout that should be there in front of him, in the middle of the crossroads, right there-is gone" (Hickey 2012: 29). Having lived and worked in Dublin all his life, Farley does not appreciate the alterations, as the pub he knew is now "pained a sickly colour for a start with a stupid-looking clock tower stuck on one side" (Hickey 2012: 29). ${ }^{24}$ In Alter's view: "Fragmentation and discontinuity have been central to the novelistic representation of urban experience" (137), ${ }^{25}$ but in Farley's case these incidents intensify his labyrinthine disorientation, and even the loss of control over his body: "Outside, the ground tilts as if it's moving always from him" (Hickey 2012: 29). In the span of seconds he experiences a sensation of slipping on the ice, but "... when he looks down his feet are steady to the ground. He feels a bit lost. Like he's fallen asleep on the bus with a few jars on him and

24 Tindall reads the tenth chapter of Ulysses as "labyrinthine drawing not only on the wandering of the main characters, but on the characters themselves" as "the labyrinth is also man" and Stephen and Bloom are "more confusing than the streets they follow" (5).

25 Paradoxically, Clery's Department store, mentioned in Ulysses (Joyce 1990: 350), remained in business until 2015, and Farley carries one of his shoes in its bag (Hickey 2012: 44). Earlier in the novel Clery's bag functions as a reminder of his dead wife, Martina, when Farley opens it and finds a catalogue and some seeds in it (Hickey 2012: 153). 
gotten off at the wrong stop" (Hickey 2012: 29). For the elderly character, not so much the "dear dirty Dublin" (Lehan 106) of young Dedalus (A Portrait) but the new post Celtic-Tiger capital becomes the maze of the streets, an otherworldly prison, ${ }^{26}$ a nightmarish space. The homeless junkies in the street, ${ }^{27}$ described as "ghosts in purgatory" (Hickey 2012: 35), ${ }^{28}$ deepen Farley's agitation. When they disappear, literally, as he does not notice the moment of their departure, he is glad: "The ghosts all departed now, Farley sighs through his teeth and squares back his shoulders; stronger now, renewed. He has walked through his fear. He's alright" (2012: 39). In other words, he has traversed the maze.

That bleak and unfriendly city of 2010, a decade earlier, in April 2000, was populated by people with purpose, and felt like a machine "about to take off" (Hickey 2012: 49). It is through the feeling of upward movement akin to flying, through the rush of the multitudes, that Hickey visualizes the euphoria of economic potential that transforms Dublin into a modern European city. Farley is proud to have noticed that "skeletons of cranes and half-constructed buildings rose up" all the way down to the sea (Hickey 2012: 49). ${ }^{29}$ Previously, in the 1980s, Dublin seemed stylish and European, and as Farley watched the St. Stephen's march on Tv, he thought a night-time city "that could be Dublin ... the river of small wobbling lights move down a boulevard that could be O'Connell Street" (Hickey 2012: 134). The affluence built on the European Union funds had been manifested in an increasing number of cars, as well as new and

26 Jaskolski talks at length about the first images of the labyrinth as a stronghold and a prison (1-51); see also McCullough (24-41). The image is also preserved in the history of the famous Maze Prison built on the outskirts of Lisburn. First named Long Kesh Detention Centre in 1941, it was rebuilt as an RAF airfield station, and renamed Her Majesty's Prison Maze in June 1972 (Ryder 105). I am grateful to Professors Joanna Kruczkowska and Leszek Drong, who reminded me about "the maze as prison image" and "prison as maze idea," respectively.

27 While waiting for his shoe to be fixed in the shopping center Farley watches people passing by and notices that most of them are fat, men, women, even children. The only skinny ones, he thinks, are the junkies or people after or before their cancer treatment (Hickey 2012: 43). The problem with obesity and related illnesses is of course one of the signum temporis and common as much in Europe as in the US and other so-called First World countries.

28 Seidel sees both Ulysses and Finnegans Wake as "ghost stories, ancestral, epic, and comic, about the complexities of multiple migrations" (18).

29 Farley, as the summons server, drives through Dublin, commenting on the sites, looking, for example, at Inchicore, and St. John's church towards Phoenix park; "a bush-covered skyscape and a slender glint from the Pope's cross" (Hickey 2012: 96). John Paul II visited Ireland in 1979. 
renovated houses. Likewise, the firm, which he had helped build, grew steadily from the 1960s (Hickey 2012: 54), taking over the consecutive apartments following the moving out or decease of their less fortunate inhabitants. Roughly at the same time as the first "take-overs," the meeting of his future wife Martina, identified as a girl from Ballyer "who says I seen and I done" (Hickey 2012: 179), prevents Farley from emigrating to Australia. ${ }^{30}$ Walking into Martina's lower class neighborhood, he becomes aware of: "An endless cram of houses behind iron-rod fences; farty gardens, door after door, number after number" (Hickey 2012: 194), his distaste with the district alleviated by his fascination with Martina herself. Though not one of the major preoccupations, but given the socio-economic provenance, the alliance between the upward movement of social classes and the development of housing districts remain at the core of Dublin's unfettered advancement observed by Farley during his numerous journeys through the city. ${ }^{31}$ In the course of decades, Hickey uses her character as a mouthpiece to witness and comment on the increase and then the collapse of various businesses, and this allows her to articulate the city's past through the prism of individual experiences. Farley's perceptions emphasize the sense of the post-Celtic Tiger crisis, while he himself, like other Dublin inhabitants, is a pawn of history, an ordinary man in the great labyrinth of life.

At the end of their journeys, Everyman and later John Bunyan's Christian in The Pilgrim's Progress were promised an Augustinian celestial city, but neither Bloom nor Farley are offered such an option. Joyce's Ulysses, showing the birds-eye view of Dublin, resonates with the myth of the peripatetic Odysseus, implicitly underscoring the fate of Rome, the city which St. Augustine deemed unholy, and whose imperial greatness was swept into the gyres of history. Hickey's narrative, filtered through a singular consciousness brings to light the labyrinthine structures of the present-day city laced with Joycean significances. Whereas Joyce records teeming urban life with the characters entangled in their daily pursuits, Hickey, highlighting the ephemeral nature of memory and the very instability of human existence, documents the last moments of Charley Grainger's life, foregrounding the inevitable demise of the character in the context of the cultural transformation of the city. She portrays an individual

30 Australia was one of the destinations for the Irish in the second half of the twentieth century (Fanning 2011: 167, 168). Both Australia and Canada had proactive policies to turn migrants into citizens (Fanning 2011: 176).

31 The correlation between space and social life is one of the understated issues touched upon in the novel, yet it falls beyond the scope of the present analysis. For more theoretical background, see Lefebvre (2005). 
in moments of confusion in time and space, whose sense of loss repeatedly distorts his perception of reality. Farley looks at a Dublin he no longer fathoms, conveying Hickey's sad stance on the remnants of the Celtic Tiger euphoria and the never-ending anti-immigrant attitudes, thereby paying homage to Joycean judiciousanti-nationalism.

\section{| Works Cited}

Alter, Robert. Imagined Cities: Urban Experience and the Language of the Novel. New Haven and London: Yale University Press, 2005.

Anderson, Benedict. Imagined Communities. London: Verso, 2006 [1983].

Attridge, Derek, ed. The Cambridge Companion to James Joyce. Cambridge: Cambridge University Press, 1999 [1990].

Beckett, Samuel. Three Novels. Molloy, Malone Dies, The Unnamable. New York: Grove Press, 1958 [1955].

Corcoran, Neil. After Yeats and Joyce: Reading Modern Irish Literature. Oxford: Oxford University Press, 2003.

Cronin, Anthony. Samuel Beckett. The Last Modernist. London: Flamingo.

Deane, Seamus. "Joyce the Irishman." The Cambridge Companion to James Joyce. Ed. Derek Attridge. Cambridge: Cambridge University Press, 1999 [1990].31-53.

Doob, Penelope Reed. The Idea of the Labyrinth: From Classical Antiquity through the Middle Ages. Ithaca and London: Cornell University Press, 1992 [1990].

Fanning, Bryan. New Guests of the Irish Nation. Dublin: Irish Academic Press, 2009.

---. Immigration and Social Cohesion in the Republic of Ireland. Manchester: Manchester University Press, 2011.

Foster, R.F. Modern Ireland. 160o-1972. London: Penguin, 1989 [1988].

Hickey, Christine Dwyer. The Dancer. Dublin: New Island, 2005 [1995].

---. The Gambler. Dublin: New Island, 1996.

---. The Gatemaker. Dublin: New Island, 2000.

--- Last Train from Liguria. London: Atlantic Books, 2009.

---. Cold Eye of Heaven. London: Atlantic Books, 2012 [2011].

---. The House on Parkgate Street and Other Dublin Stories. Dublin: New Island, 2013.

---. The Narrow Land. London: Atlantic Books, 2019.

Howes, Marjorie and John Kelly, eds. The Cambridge Companion to W. B. Yeats. Cambridge: Cambridge University Press, 2006. 
Jaskolski, Helmut. The Labyrinth: Symbol of Fear, Rebirth, and Liberation.

Boston and New York: Shambhala; Prospect Hills, Illinois: Waveland Press, Inc., 1997.

Joyce, James. Ulysses: The Complete and Unabridged Text. New York: Vintage International, 1990 [1934].

---. Occasional, Critical, and Political Writing. Ed. Kevin Barry. Trans. Conor Deane. Oxford: Oxford University Press, 2000a [1993].

---. A Portrait of the Artist as a Young Man. [Edited by Jeri Johnson]. Oxford: Oxford University Press, 20oob [1964].

---. Dubliners. [Edited by Jeri Johnson]. Oxford: Oxford University Press, 2000c [1967].

Kearney, Richard. Postnationalist Ireland: Politics, Culture, Philosophy. London: Routledge, 1997.

---. On Stories. London and New York: Routledge, 2002.

Kiberd, Declan. Inventing Ireland: The Literature of the Modern Nation. London: Vintage, 1996 [1995].

Lefebvre, Henri. The Production of Space. Trans. Donald Nicholson-Smith. Oxford: Blackwell Publishing, 2005 [1991].

Lehan, Richard. The City in Literature: An Intellectual and Cultural History. Berkeley: University of California Press, 1998.

Lloyd, David. Anomalous States: Irish Writing and the Post-Colonial Moment. Durham: Duke University Press, 1993.

Lofland, Lyn H. A World of Strangers. Order and Action in Urban Public Space. Prospect Heights, Illinois: Waveland Press, Inc., 1973.

Longley, Edna, and Declan Kiberd. Multi-Culturalism: The View from the Two Irelands. Cork: Cork University Press, 2001.

McCullough, David Wills. The Unending Mystery: A Journey Through Labyrinths and Mazes. New York: Anchor Books, 2004.

Pakenham, Thomas. The Year of Liberty. The Great Irish Rebellion of 1798. London: Abacus, 2004 [1969].

Paziński, Piotr. Dublin z Ulissesem. [Dublin with Ulisses]. Warszawa: Czuły Barbarzyńca Press, 2008.

Ryan, Donal. All we Shall Know. London: Black Swan, 2017 [2016].

Ryder, Chris. Inside the Maze. The Untold Story of the Northern Ireland Prison Service. London: Methuen, 2001 [2000].

Seidel, Michael. Epic Geography: James Joyce’s Ulysses. [Maps drawn by Thomas Crawford]. Princeton: Princeton University Press, 1976.

Tindall, W. Y. James Joyce: His Way of Interpreting the Modern World. New York: Charles Scribner and Sons, 1950. 
Vendler, Helen. “The Later Poetry." The Cambridge Companion to W. B. Yeats.

Eds. Marjorie Howes and John Kelly, 2006. 77-100.

Welch, Robert. Changing States: Transformations in Modern Irish Writing.

London: Routledge, 2004 [1993].

\section{| Abstract \\ LiLIANA SiKorSKa \\ In the Labyrinth of Forgetfulness: Charley Grainger's Joycean Journey in Christine Dwyer Hickey's Cold Eye of Heaven}

Cold Eye of Heaven (2011) shows pre-Brexit Dublin steeped in the post-Celtic Tiger anxieties. The novel narrates the life of a contemporary Everyman, Charley Grainger, known as Farley, from his final moments back to his childhood. Thus, Farley's journey envisages both a Joycean interior monologue depicting his old-age bafflement in the meanders of memory and a realistic description of the character's bewilderment at the changes in the cityscapes of the Dublin of 2010. The present paper is a comparative study of the first two chapters of the novel in reference to the history of the city present in the entire text, through the use of the tropes of the mental and urbane labyrinths. Imbued with the allusions to current reality, i.e., the presence of immigrants, Hickey's observations are in line with Joycean anti-nationalism, as the story offers a nostalgia-stricken picture of the inevitable economic transformation of the metropolis.

Keywords: labyrinth; city; memory; nationalism; anti-nationalism

\section{| Abstrakt}

LILIANA SIKORSKA

W labiryncie niepamięci: śladami Charleya Graingera, bohatera Cold Eye of Heaven Christine Dwyer Hickey

Cold Eye of Heaven pokazuje Dublin przed brexitem, zanurzony w niepokojach po Celtyckim Tygrysie. Powieść opowiada historię przeciętnego człowieka, Charleya Graingera, zwanego Farleyem, od momentu śmierci do jego przyjścia na świat. Sposób prowadzenia narracji odnosi się zarówno do Joyce’owskiego monologu wewnętrznego, pokazując starcze zagubienie bohatera w meandrach (nie)pamięci, 
jak i do realistycznego opisu zmian, jakie zaszły we dzisiejszym Dublinie. Niniejszy artykuł jest porównawczą analizą powieści poprzez tropy labiryntu i miasta. Nasycone odnośnikami do współczesności, np. do obecności emigrantów, obserwacje Hickey są zgodne z poglądami Joyce’a dotyczącymi antynacjonalizmu, oferując nostalgiczny obraz nieuchronnej ekonomicznej transformacji.

Słowa kluczowe: labirynt; miasto; pamięć; nacjonalizm; antynacjonalizm

\section{| About the Author}

Liliana Sikorska-Head, Department of English Literature and Literary Linguistics, Faculty of English, Adam Mickiewicz University, Poznań. President, International Association of University Professors of English 2016-2019. Academic interests comprise medievalism and orientalism, Celtic and Irish cultures and English literature. Her publications include: Ironies of Art/Tragedies of Life: Essays on Irish Literature (ed. 2005), A Universe of (hi)stories: Essays on J.M. Coetzee (ed. 2006). She has also authored An Short History of English Literature (fourth edition 2011). She is the general editor of An Outline History of English Literature in Texts. Vol I- III (2007) and general editor of An Outline History of Irish Literature in Texts (2011). Her most recent publication is Other Encounters: Reading the Medieval Orient in the Nineteenth and Twentieth Century Narratives (to be published by de Gruyter, Berlin and Medieval Institute Publications, Michigan, 2021).

E-mail: sliliana@amu.edu.pl

ORCID: OOOO-0001-7293-5532 